\title{
Anabases
}

ANABASES Traditions et réceptions de l'Antiquité

19 | 2014

Varia

\section{What distinguishes Ovid's Pythagoras from the Pythagoras of Ausonius and Martianus Capella?}

\author{
Matthew M. McGowan
}

\section{(2) OpenEdition}

1 Journals

Édition électronique

URL : http://journals.openedition.org/anabases/4659

DOI : 10.4000/anabases.4659

ISSN : 2256-9421

Éditeur

E.R.A.S.M.E.

\section{Édition imprimée}

Date de publication : 1 avril 2014

Pagination : 189-204

ISSN : 1774-4296

\section{Référence électronique}

Matthew M. McGowan, « What distinguishes Ovid's Pythagoras from the Pythagoras of Ausonius and Martianus Capella? », Anabases [En ligne], 19 | 2014, mis en ligne le 01 avril 2017, consulté le 20 octobre 2019. URL : http://journals.openedition.org/anabases/4659; DOI : 10.4000/anabases.4659 


\section{What distinguishes Ovid's Pythagoras from the Pythagoras of Ausonius and Martianus Capella?}

MatThew M. McGowan

- mente deos adiit

(Ovid, Met. 15.63)

This paper eXamines the Reception of OVID's representation of the figure of Pythagoras in the works of Ausonius and Martianus Capella ${ }^{1}$. Why Ausonius and Martianus Capella? The answer to this question has as much to do with the subsequent history of the figure of Pythagoras in medieval Latin literature as with Ovid's own influence on both authors. For Ausonius and Martianus are typical of and, to a large degree, determinative for the representation of Pythagoras as a mathematician, musician and, generally, ethical sage common in late-antique and medieval literature and $\mathrm{art}^{2}$. Moreover, Ovid's stylistic

1 The Latin texts regularly cited in this article are: W.S. Anderson, P. Ovidii Nasonis Metamorphoseon Libri XV, Leipzig, 1977; A.L. WheELER, Ovid: Tristia and Epistulae ex Ponto, Cambridge, MA, 1924 (2 ${ }^{\text {nd }}$ ed., revised by G.P. Goold, 1988); J.A. Richmond, P. Ouidii Nasonis ex Ponto Libri Quattuor, Leipzig, 1990; R.P.H. Green, Decimi Magni Ausonii Opera, Oxford, 1999; J. Willis, Martianus Capella, Leipzig, 1983.

2 C.L. Joost-Gaugier, Measuring Heaven: Pythagoras and his Influence on Thought and Art in Antiquity and the Middle Ages, Ithaca, NY, 2006, p. 58, 60-61, 67, 76. For the conventional appellation - musicus "musician"- see Cassiodorus, Variae 1.45.4 [addressed to Boethius]: Translationibus enim tuis Pythagoras musicus, Ptolemaeus astronomus leguntur Itali: Nicomachus arithmeticus, geometricus Euclides audiuntur Ausonii: Plato theologus, Aristoteles logicus Quirinali voce disceptant. ("For on account of your translations, 
influence on both authors is well-known ${ }^{3}$, and both write enough about Pythagoras to offer fitting test-cases, as it were, to evaluate whether what I see as significant in Ovid's representation is also of concern in later authors.

\section{Ovid's Pythagoras}

Pythagoras does not appear often in Ovid, but at the end of the Metamorphoses (15.75478) he makes a lengthy speech, which has often been viewed as integral to the interpretation of the poem as a whole and has thus received significant scholarly attention ${ }^{4}$. The Pythagoras-episode's popularity among critics is hardly surprising given that it is the epic's longest single set-speech, occurs towards the end of the poem, and involves a famous philosopher who straddles the world of history and myth, a liminal figure between man and god, and thus an ideal subject for Ovid's artistry. In the episode itself Pythagoras appears as a committed vegetarian, a purveyor of metempyschosis -the theory of the eternal reincarnation of the soul- and, more generally, an ethical philosopher promoting the idea of perpetual change in the physical universe. These are all familiar guises from the lengthy and variegated picture of Pythagoras in antiquity, although Ovid stresses that his great intellect gives him access to divine knowledge for disclosing the nature of the universe, Met. 15.60-76:

Pythagoras the musician and Ptolemy the astronomer are read as native Italians; Nicomachus the arithematician and Euclid the geometrist are heard as native Ausonians; Plato and Aristotle, masters of the divine and logic respectively, debate in the language of Romulus.")

3 For Ausonius, see B. Combeaud, D.M. Ausonii Burdigalensis Opuscula Omnia. Texte établi, traduit, et commenté, Bordeaux, 2010, p. 22, and passim under the index heading "loci similes", p. 829-870; R.P.H. GreEN, The Works of Ausonius. Edited with introduction and commentary, Oxford, 1991, p. xx. For Martianus Capella, see L. CRISTANTE, Martiani Capellae de Nuptiis Philologiae Mercurii Liber IX. Introduzione, traduzione, e commento, Padova, 1997, p. 75 n. 6, 80 n. 34, 186-187; W.H. STAHL, Martianus Capella and the Seven Liberal Arts, volume I, The Quadrivium of Martianus Capella: Latin Traditions in the Mathematical Sciences, 50 B.C. - A.D. 1250, With a Study of the Allegory and the Verbal Disciplines by R. Johnson with E.L. Burge, New York, 1971, p. 40, 85.

4 Pythagoras receives mention in nearly every monograph on Ovid; the following works present discrete discussions: G.K. GaLINSKY, "The Speech of Pythagoras at Ovid Metamorphoses 15, 75-478”, in F. Cairns \& M. Heath (eds), Papers of the Leeds International Latin Seminar 10 (1998), p. 313-336; P. HARDIE, "The Speech of Pythagoras in Ovid Metamorphoses 15: Empedoclean Epos", Classical Quarterly 45 (1995), p. 204-214; R. Segl, Die Pythagorasrede im 15. Buch von Ovids Metamorphosen. Diss. Salzburg, 1970; C. SEgal, "Myth and Philosophy in the 'Metamorphoses': Ovid's Augustanism and the Augustan Conclusion of Book XV", American Journal of Philology 90 (1969), p. 257-292; E. Saint-Denis, "Le génie d'Ovide d'après le livre XV des Métamorphoses", Revue des Études Latines 18 (1940), p. 111-140. 
uir fuit hic ortu Samius, sed fugerat una et Samon et dominos odioque tyrannidis exul sponte erat isque licet caeli regione remotus mente deos adiit et, quae natura negabat uisibus humanis, oculis ea pectoris hausit, cumque animo et uigili perspexerat omnia cura, in medium discenda dabat coetusque silentum dictaque mirantum magni primordia mundi et rerum causas et, quid natura, docebat, quid deus, unde niues, quae fulminis esset origo, Iuppiter an uenti discussa nube tonarent, quid quateret terras, qua sidera lege mearent, et quodcumque latet, primusque animalia mensis arguit inponi, primus quoque talibus ora docta quidem soluit, sed non et credita, uerbis: 'Parcite, mortales, dapibus temerare nefandis corpora!

("There was a man here, a Samian by birth, but he had fled Samos together with its rulers, and through hatred of tyranny was living in voluntary exile. Though himself removed from the region of heaven, he approached the gods with his intellect, and what nature denied to human sight, he drank in with the mind's eye. When he had finished investigating everything with steady thought and care, he shared what there was to learn with the public and taught gatherings of listeners, stunned to silence by his words, about the elements of the vast earth and the natural causes for things: for example, what nature is, what constitutes divinity, where snow comes from, what the origin of lightening is -whether Jupiter or the wind thunders when a cloud has been split- what shakes the earth, by what law the stars wander, and whatever else goes unnoticed. He was the first to make the case that animals not be served as food; he was the first, too, to share his teachings, albeit not to be believed, in words such as these: 'O mortal men, stop defiling your bodies with unspeakable feasts!'”)

From Ovid's preamble introducing Pythagoras up to the start of the philosopher's speech itself (v. 75: parcite, mortales...), the focus of inquiry shifts from science and learning to a concern for what men do; in terms of ancient philosophy, the difference here is between physics and ethics, or rather between the study of the natural world (natura) and the guiding of human behavior (mores). Pythagoras will later move onto (a kind of) metaphysics and summarize his teaching on the eternal nature of the soul (15.143-172), a teaching that can also be brought to bear on his moralizing injunction against meat-eating, Met. 15.173-75: ergo, ne pietas sit victa cupidine ventris, I parcite, vaticinor, cognatas caede nefanda / exturbare animas, nec sanguine sanguis alatur 
("Therefore, lest pious obligation be overcome by the belly's craving -I speak as a prophet- stop banishing kindred souls by wicked slaughter; let no blood be nourished by blood.")

The ban on meat-eating and the theory of metempsychosis on view here are among the most recognizable features of any representation of Pythagoras, especially the stock caricatures familiar from Roman poetry ${ }^{5}$. Perhaps less familiar is the philosopher's status as political exile, as seen at the outset of the above passage, Met. 15.60-62: uir fuit hic ortu Samius, sed fugerat unal et Samon et dominos odioque tyrannidis exul / sponte erat. ("There was a man here, a Samian by birth, but he had fled Samos together with its rulers, and through hatred of tyranny was living in voluntary exile.") Recognizing Pythagoras' status as a political exile in the Metamorphoses ought naturally to lead the reader to reflect on how that status relates to Ovid's own exile in the year 8 AD. For reasons that have remained shrouded in mystery, the Roman emperor, Caesar Augustus, took it upon himself to send Rome's most celebrated poet to the distant and, to read Ovid at least, unbearably frigid town of Tomis on the western coast of the Black Sea in what is now Constanza, Romania. Of course, in the second book of the Tristia, or "Sad Songs" he wrote while in exile, Ovid claims that he was banished -or rather "relegated" - by the emperor personally on two charges, a poem and a mistake, Tr. 2.207: duo crimina, carmen et error ("two charges, a poem and a mistake"). The poem or carmen, he tells us on several occasions, was the Ars Amatoria; the exact nature of the mistake or error he never reveals ${ }^{7}$. A full explanation of the causes behind Ovid's exile, it seems, has been trumped by history; for no solution to the problem, however

5 Belonging to those caricatures is, no doubt, Hor. Satires, 2.6.63: faba Pythagorae cognata ("Pythagoras' relative, the bean"), but see Hor. Epist. 2.1.50-1: Ennius, et sapiens et fortis et alter Homerus, / ut critici dicunt ("The critics call Ennius 'another Homer', both wise and accomplished in epic”), on which Porph. ad Hor. Epist. 2.1.51: quod secundum Pythagorae dogma anima Homeri in suum corpus uenisset. ("because in accordance with Pythagoras' teaching the soul of Homer had come into his body.") Of course, Ennius had himself written (fr. 3 Skutsch): uisus Homerus adesse poeta ("the poet Homer appeared to be present"), and was in any case surely familiar with Pythagorean thought.

$6 \quad \operatorname{Tr}$. 2.137: quippe relegatus, non exul, dicor in illo [edicto] ("Indeed, in your edict I'm said to be 'relegated', not 'exiled'”), cf. Tr. 1.7.8; 5.217; 5.11.21; Pont. 4.15.2 and I. Ciccarelli, Commento al II Libro dei Tristia di Ovidio, Bari, 2003, p. 126 ad Tr. 2.137: "In questo caso... la distinzione tra exul e relegatus cela un intento polemico: al poeta, infatti, poco importa il significato giuridico dei due termini, poiché nella sua condizione relegatus è solo un eufemismo che cela una pena dura e dolorosa al pari dell' exilium."

7 On the Ars as one of the contributing causes of his exile, $\operatorname{Tr}$. 1.1.67-8; 2.212; 2.345-7; 2.539-46; 5.12.67-8: sic utinam, quae nil metuentem tale magistrum/perdidit, in cineres Ars mea uersa foret! "Would that I had burned my Art, which has destroyed its master who feared nothing of this kind!"; Pont. 2.9.75-6. On the silence he must keep regarding his error, Tr. 2.207-8: perdiderint cum me duo crimina, carmen et error, I alterius facti culpa silenda mibi "though charges for two crimes have brought me to ruin - a poem and a mistake - I must keep silent the fault of the latter deed”; 4.10.99-100. 
ingenious, can lay claim to certainty and few have ever met with approval for long ${ }^{8}$. Not surprisingly, there have been attempts to show that Ovid was never actually banished and that his exile is a poetic fiction ${ }^{9}$, but such an elaborate fiction, without precedent or parallel in antiquity, is improbable even for a poet as innovative as Ovid. Perhaps less improbable is the notion that the Metamorphoses can be brought into close relation with the poet's work in exile, the Tristia, Ibis, and Epistulae ex Ponto ${ }^{10}$. Indeed, Ovid's sprawling epic on changing forms in myth and history was "published" in the very year of Ovid's banishment ( $8 \mathrm{AD}$ ), and some consensus seems to be building that at least certain passages in the poem were revised during the period of the poet's exile ${ }^{11}$.

\section{Pythagoras and Numa}

A connection between Ovid as banished poet and Pythagoras as exiled philosopher has been suggested by Philip Hardie ${ }^{12}$, and it would be worthwhile to pursue Hardie's line of argument further. For the present paper, however, I would like to focus on the role of Numa in Ovid's various Pythagoras-episodes, a comparatively neglected feature of the scholarly criticism on those episodes ${ }^{13}$. As in the Metamorphoses passage quoted above, in the passages cited below the legendary second king at Rome is imagined by

8 J.C. Thibault, The Mystery of Ovid's Exile, Berkeley-Los Angeles, CA, 1964, catalogues well over one hundred attempts since $400 \mathrm{AD}$ to solve the mystery of Ovid's exile and is forced to conclude, p. 121: "None is completely satisfactory... certainty can never be attained on the basis of our present resources."

9 A.D. FitTon Brown, "The Unreality of Ovid's Tomitan exile", Liverpool Classical Monthly 10.2 (1985), p. 18-22; J.J. HarTMAn, De ovidio poeta, Leyden, 1905, p. 70. For a summary of the Fiktionsthese, B. CHWALEK, Die Verwandlung des Exils in die elegische Welt. Studien zu den Tristia und Epistulae ex Ponto Ovids, Frankfurt a. M., 1996, p. 28-31; and for clear arguments against it, D. LitTle, "Ovid's last poems: Cry of pain from exile or literary frolic in Rome?” Prudentia 22 (2009), p. 29-39.

10 M.M. McGowan, Ovid in Exile: Power and Poetic Redress in the Tristia and Epistulae ex Ponto, Boston-Leiden, 2009, p. 7, 125-127.

11 On possible post-exilic revisions of the Metamorphoses, see J.A. Richmond, "Manuscript Traditions and the Transmission of Ovid's Works", in B. Weiden Boyd (éd.), Brill's Companion to Ovid, Leiden-Boston-Köln, 2002, p. 443-483.472-74; E.J. Kenney, "Ovid", in W. Clausen et E. J. Kenney (eds), Cambridge History of Classical Literature, vol. 2., Cambridge, 1982, p. 444 n. 1; M. Pohlenz, "Die Abfassungszeit von Ovids Metamorphosen", Hermes 48 (1913), p. 1-13; on the Fasti as an "exile-poem", see A.J. BoyLE, "Postscripts from the Edge: Exilic Fasti and imperialised Rome", Ramus 26.1 (1997), p. 7; D.C. Feeney, "Si licet et fas est. Ovid's Fasti and the Problem of Free Speech under the Principate", in A. Powell (ed.), Roman Poetry and Propaganda in the Age of Augustus, London, 1992, p. 14-19.

12 P. Hardie, Ovid's Poetics of Illusion, Oxford, 2002, p. 308.

13 A notable exception is provided by C. Crahay \& J. Hubaux, "Sous le masque de Pythagore, à propos du livre 15 des Métamorphoses”, in N.I. Herescu (ed.), Ovidiana. 
Ovid to have been taught by Pythagoras and then to have brought back home his lessons on Greek philosophy (and the nature of the universe). As a reputed lover of peace and founder of ritual practice and sacred law at Rome, Numa stands diametrically opposed to his predecessor Romulus. In Dumézil's famous formulation, he is the priest-king of religious foundation and legal formulation to Romulus' warrior-king of martial prowess and urban defense ${ }^{14}$. It is clear that both Julius Caesar and Augustus invoked Numa and not Romulus as a model of a pious and peaceful ruler when they seized power after an extended spate of civil wars ${ }^{15}$. To be sure, both cultivated the appearance that -like Numa- they stood for piety and peace, even if they were -after Romulus- Romans in name. In the final book of the Metamorphoses, Ovid considers how the people of Italy eventually became Romans -a metamorphosis of an historical rather than mythical nature- by exploiting the popular legend of Pythagoras and Numa.

According to tradition -and Ovid is one of our sources for the tradition- Numa had been a student of Pythagoras at Croton in southern Italy, Fasti 3.151-54: primus oliuiferis Romam deductus ab aruis/ Pompilius menses sensit abesse duos, / siue hoc a Samio doctus, qui posse renascil nos putat, Egeria siue monente sua. ("Numa Pompilius, who was brought to Rome from the fields where olives grow, was the first to realize that two months were missing from the year, whether he was taught by the Samian [Pythagoras], who believes that we can be reborn, or whether it was Egeria who told him.") Later, in the Epistulae ex Ponto, in the midst of a catalogue of a familiar type in the exile poetry, Ovid adduces mythic examples of students who brought no harm to their teachers, ex

Recherches sur Ovide, Paris, 1958, p. 283-300, especially p. 299 where "Numa est la préfiguration d'Auguste."

14 Cf. G. DuméZIL, Archaic Roman Religion, Chicago, 1970, p. 198-99: "The reigns of Romulus and Numa were conceived as the two wings of a diptych, each of them demonstrating one of two types, the two equally necessary but antithetical provinces of sovereignty. Romulus is a young demigod, impetuous, creative, violent, unhampered by scruples, exposed to the temptations of tyranny; Numa is a completely human old man, moderate, an organizer, peaceful, mindful of order and legality.» Of course later (p. 523), DumÉzIL notes that "for many Romans Numa was still the pythagorean king, a valuable and ancient link between Greece and Rome, between wisdom and politics." For Livy's treatment of the Romulus-Numa pair, cf. D. Levene, Religion in Livy, Leiden, 1993, p. 131-137, who cites (n. 19) the more general discussion of the indo-european warrior-king and priest-king in G. DumÉZIL, Mitra-Varuna: essai sur deux représentations indo-européennes de la souveraineté, Paris, p. 27-56. For a judicious account of the much pointed criticism DumÉzIL's model -the so-called "idéologie tripartite"- has received, see W.W. Belier, Decayed Gods: Origin and Development of Georges Dumézil's Idéologie Tripartite, Leiden, 1991.

15 R.J. LitTlewood, "Imperii pignora certa: The Role of Numa in Ovid's Fasti", in G. Herbert-Brown (ed.), Ovid's Fasti, Historical Readings at its Bimillennium, Oxford, 2002, p. 175-197, analyzes the Romulus-Numa antithesis to show how "Numa fits into the essential duality of Augustan iconography" (p. 176). Cf. R.M. Ogilvie, A Commentary on Livy Books 1-5, Cambridge, 1965, p. 85. 
Ponto 3.3.43-4: praemia nec Chiron ab Achille talia cepit,/ Pythagoreaeque ferunt non nocuisse Numam ("But Chiron got no such payment from Achilles, and they say that Numa did no harm to Pythagoras.”).

It is difficult to say whether the Numa-Pythagoras, student-teacher legend stems from a Greek or Roman source ${ }^{16}$, but the tradition was well established by the time of Cicero. Both he and Livy comment on the chronological impossibility of having Pythagoras teach Numa, who ruled about 150 years before the exiled philosopher ever landed on Italian shores in around 530 BC. Yet both authors acknowledge the extent to which the foundations of Roman culture were influenced by Pythagorean thought ${ }^{17}$. Numa's reputed interest in sacred law and social harmony seems to have reminded Italy's educated class of Pythagoras and of the Pythagorean commitment to philosophy as a way of life ${ }^{18}$. Pythagoras' sect was viewed as a distinctly Italian phenomenon and

16 Cf. L. Ferrero, Storia del Pitagorismo nel mondo romano, Turin, 1955 and E. GabBA, "Considerazioni sulla tradizione letteraria sulle origini della Repubblica", in E. GJERSTAD et al. (eds), Les origines de la république romaine, Entretiens sur l'Antiquité classique 13, Geneva, 1967, p. 135-169, who posit a fourth-century Greek source, probably from Tarentum and perhaps Aristoxenus, a student of Pythagoreanism and Aristotle, music theorist, and the author of a lost life of Pythagoras, which is believed to be the source for Iamblichus' De Vita Pythagorae. For a (hellenized) Roman source, see M. Humm, "Numa et Pythagore: vie et mort d'un mythe", in P.-A. Deproost and A. Meurant (eds), Images d'origines. Origines d'une image. Hommages à Jacques Poucet, Louvain, 2004, p. 125-137; P. PAnitscheK, "Numa Pompilius als Schüler des Pythagoras", Grazer Beiträge 17 (1990) p. 49-65. For a review of scholarship on the problem, A. STORCHIMarino, "Il Pitagorismo romano. Per un bilancio di studi recenti", in M. Tortorelli Ghidini, A. Storchi-Marino, A. Visconti (eds), Tra Orfeo e Pitagora. Origini e incontri di culture nell'Antichità, Naples, 2000, p. 335-366. Cf. E. Dench, Romulus' Asylum: Roman Identities from the Age of Alexander to the Age of Hadrian, Oxford, 2005, p. 177, on Pythagorean interest from the $3^{\text {rd }}$ cent. BC in Numa as a figure of Sabine (rather than Roman) ethnicity.

17 Cic. Tusc. 4.2: erat enim illis (sc. maioribus nostris) paene in conspectu praestanti sapientia et nobilitate Pythagoras, qui fuit in Italia temporibus iisdem quibus L. Brutus patriam liberauit ("For almost within sight of our ancestors was Pythagoras who lived in Italy at the same time L. Brutus freed his country"); id. 4.4: et deorum puluinaribus et epulis magistratuum fides praecinunt quod proprium eius fuit de qua loquar disciplinae (sc. Pythagoreae) ... multa etiam sunt in nostris institutis ducta ab illis (Pythagoreis), quae praetereo ne ea quae repperisse ipsi putamur aliunde didicisse uideamur. "Stringed instruments play before the staged seatings of the gods and feasts of the magistrates which was a special feature of that [Pythagorean] training I am talking about... and I'll pass over the many things that have been taken over from the Pythagoreans in our own institutions lest we appear to have learned from elsewhere things we are thought to have discovered ourselves.")

18 Perhaps best illustrated in the following passage from Met. 15.153-75: O genus attonitum gelidae formidine mortis!/ quid Styga, quid tenebras et nomina uana timetis, / materiem uatum, falsique pericula mundi?/ corpora, siue rogus flamma seu tabe uetustas/ abstulerit, mala posse pati non ulla putetis:/ morte carent animae semperque priore relictal sede nouis domibus uiuunt habitantque receptae./ ipse ego (nam memini) Troiani tempore belli/ Panthoides 
thus spoke to a feeling of national pride at Rome, a city that became -on the model of Numa- more interested in redressing its lack of philosophical sophistication. With the help of Pythagoras, Numa does double duty for an increasingly sophisticated class of Romans eager to acquire both the intellectual riches of Hellenic culture and to maintain what made them distinctly Roman.

Whether Numa was in fact a man of philosophical mettle like Pythagoras- or whether he existed at all ${ }^{19}$ !- is beside the point. In Latin literature Numa becomes a sage and ethical reformer on the model of one of the greatest ethical reformers in the Greek (and Italian) tradition. Herein lies the appeal of Numa and Pythagoras to Ovid in his Metamorphoses, where the poet recreates a chronological continuum via Greek myth and Roman history from the origins of the universe to contemporary Rome. The natural end to this mytho-historic epic is the apotheosis of Rome's most recent leaders, Julius Caesar and his adoptive son Caesar Augustus Octavianus, an apotheosis explicable only by way of Rome's extensive contact with the Greek east. In a separate study from the one cited above, Philip Hardie has argued that the Pythagoras of Ovid's poem channeled Greek thinkers such as Euhemerus and Empedocles who made it theoretically possible for men - great men, of the kind both Caesar and Augustus considered themselves to be - to bridge the gap between mortality and divinity, to pass over death and become, at least in theory, gods. ${ }^{20}$ In short, Ovid's use of the Pythagoras-Numa

Euphorbus eram, cui pectore quondam/ haesit in aduerso grauis hasta minoris Atridae./ cognoui clipeum, laeuae gestamina nostrae, / nuper Abanteis templo Iunonis in Argis./ Omnia mutantur, nibil interit: errat et illincl huc uenit, hinc illuc et quoslibet occupet artus/ spiritus eque feris humana in corpora transit/ inque feras noster, nec tempore deperit ullo, / utque nouis facilis signatur cera figuris/ nec manet, ut fuerat, nec formas seruat easdem, I sed tamen ipsa eadem est, animam sic semper eandem/ esse sed in uarias doceo migrare figuras./ ergo, ne pietas sit uicta cupidine uentris, / parcite, uaticinor, cognatas caede nefandal exturbare animas, nec sanguine sanguis alatur. ("A living race thunder-struck by the fear of an icy death! Why do you fear the Styx? why the underworld and mere names, the stuff of poets and dangers of an imaginary world? Do not think that our bodies, whether consumed by the flame of the funeral pyre or the wasting away of old age, are able to suffer any harm. Death does not touch our souls and when they leave their former seat, they continue to live, always received in new abodes. At the time of the Trojan War I myself (as I recall) was once Panthous' son, Euphorbus, whom the heavy spear of the lesser son of Atreus once impaled in the heart. Recently I recognized the shield I used to bear on my left arm hanging on the temple of Juno at Abas in Argos. All things change; nothing dies: the soul wanders, going from here to there and from there to here, occupying whatever limbs it will, moving from beast to human and from human to beast and never dying. Even as impressionable wax is marked by new etchings, never staying as it was, never keeping the same form and yet it is the same, so do I say is the soul, always the same even as it changes shape. And so, let not piety be overcome by the belly's craving. I warn you as a seer: stop banishing kindred souls by impious murder, and let not blood be nourished by blood.”).

19 Cf. OgiLvie, Commentary on Livy, p. 89.

20 Hardie, "The Speech of Pythagoras in Ovid Metamorphoses 15", p. 213. 
legend has political implications that are themselves wrapped up in further questions of religion and deification.

In the post-Ovidian tradition, however, Rome's legendary second king is essentially dropped from the story of Pythagoras. ${ }^{21}$ In addition, the Pythagoras we find in Ovid's Metamorphoses -the political exile teaching Numa about the perpetually changing face of the natural universe, the immortality of the soul, and the need to ban meat-eating- is mostly missing from the corresponding representations of Pythagoras in Ausonius of Bordeaux ( 310 - c. $395 \mathrm{AD}$ ) and Martianus Capella ( $f$ l. early $5^{\text {th }}$ cent.). In fact, this is true of almost any representation in the post-Ovidian tradition, starting with Ovid's near contemporaries Valerius Maximus and Velleius Paterculus, and later Aulus Gellius and Apuleius, as well as St. Jerome and St. Augustine: in none of these is Pythagoras a political exile, but rather a musician, mathematician, and sage, whose closeness to Plato is taken for granted. In short, the image familiar from Ausonius and Martianus, who of course had many sources other than Ovid for their information on Pythagoras, appears to be at odds with what we see in the Ovidian text. And yet for Ausonius, as I shall point out below, Pythagoras continues to be associated with ethical behavior and wise decision-making or what I have identified above as a concern for human behavior (mores). In Martianus Capella's case, the influence of Pythagoras and, more generally, of (neo-)Pythagorean thought lies at the core of much of the scientific knowledge of math, astronomy, and music we find in the De Nuptiis. ${ }^{22}$ In a certain sense, the outsized intellect of Martianus' Pythagoras makes him like Ovid's version of the philosopher in the Metamorphoses: they both partake of divine knowledge. In order to determine the extent to which these representations are related and, moreover, to address what distinguishes them from one another, a full investigation of the figure of Pythagoras in the works of Ausonius and Martianus Capella is in order.

\section{Pythagoras in Ausonius}

Starting with Ausonius, we encounter in a letter to Paulinus of Nola, who had apparently been remiss in responding to Ausonius' previous missives, a lesson in

21 With the notable exception of Plutarch's Life of Numa (1.2), which preserves the legend of Pythagoras teaching Numa.

22 The secondary literature here is vast, and some of it I cite below in n. 29 including I. НаDот, Arts libéraux et philosophie dans la pensée antique, Paris, 1984, p. 137-155, especially p. 145-148, 154-155; S. Grebe, Martianus Capella, "De nuptiis Philologiae et Mercurii", Darstellung der Sieben Freien Künste und ihrer Beziehungen zueinander, Stuttgart-Leipzig, 1999, p. 621-625; M. BoveY, Disciplinae Cyclicae, L'organisation du savoir dans l'cuvre de Martianus Capella, Trieste, 2003, p. 73, 260-267, 323; R. TuRCAN, "Martianus Capella et Jamblique", Revue des Études Latines 36 (1958) p. 235-254; L. LenAZ, Martiani Capellae De nuptiis Philologiae et Mercurii liber secundus. Introduzione, traduzione, e commento, Padova, 1975. 
epistolographic propriety. Here Pythagoras serves as the point of comparison for some light-hearted, ethical instruction, Epist. 21.38-42 (Paulino sc. Nolensi):

est etenim comis brevitas. sic fama renatum

Pythagoram docuisse refert: cum multa loquaces

ambiguis sererent verbis, contra omnia solum

"est" respondebat vel "non". o certa loquendi

regula!

("For brevity is indeed polite. Thus, legend has it that Pythagoras, once reborn, taught the following: when babblers would string together mouthfuls with indecisive words, to everything he used to respond simply 'Yes' or 'No'. O what a steadfast rule of speech!")

Even if his response be short, Ausonius states, at least let it be something; Paulinus need only write! In this case, Pythagoras is adduced as a model for proper behavior, and while Ausonius' admonition is clearly meant to be humorous, it nevertheless points to how one should behave and is thus in the strictest sense "ethical".

Another lament for proper behavior follows in our next passage, this time in a genuinely more serious vein in Ausonius' address in verse to his prematurely deceased nephew, Herculanus. The letter stems from his collection commemorating the Professors of Bordeaux, and I quote it in full here, Prof. 11.1-7:

Herculane, qui, profectus gremio de nostro et schola,

spem magis, quam rem fruendam praebuisti avunculo,

particeps scholae et cathedrae paene successor meae,

lubricae nisi te iuventae praecipitem flexus daret,

Pythagorei non tenentem tramitis rectam viam:

esto placidus et quietis manibus sedem fove,

iam mihi cognata dudum inter memoratus nomina.

(“Although you set forth from my lap and my teaching, Herculanus, you offered your uncle only the hope of fruition rather than the thing itself. You shared my teaching and might have become successor to my chair, if the swerve of slippery youth had not brought you down headlong because you did not take the right branch of the Pythagorean path. Be at rest and cherish your place among the quiet shades, you, now long mentioned among the names of my relatives.")

Ausonius' lament for the untimely death of his nephew and fellow professor, Herculanus, depends on the famous "Two Ways of Pythagoras", the so-called bivium 
or Greek diodia, symbolized by the capital letter upsilon $(\mathrm{Y})^{23}$. For the Pythagoreans, the two branches of the upsilon represented a choice for good or for bad left to the young upon entering adulthood. For Ausonius the symbol serves to explain his nephew's misfortune: Herculanus failed to choose the right path as a young man and met his downfall because of it.

A similar emphasis on ethical instruction -and the same Pythagorean symbol used to convey the importance of making morally sound choices when passing from youth to adulthood- informs our next passage from Ausonius' Technopaegnia. The title means "playful excercises" or "trifles done with skill" and also refers to the distinct physical shape or figures these poems have, as here, Technop. 13.8-10:

Cecropiis ignota notis, ferale sonans $V$.

Pythagorae bivium, ramis pateo ambiguis $Y$.

vocibus in Graecis numquam ultima conspicior $M$.

("A stranger to the Cecropian alphabet is ominous-sounding V. I stretch forth arms in two directions, the Two Ways of Pythagoras -I am Y. I am a letter never found at the end of Greek words- I am M.”)

The letter Y representing Pythagoras' bivium (or "Two Ways") is among the more popular images associated with Pythagorean morality in late antiquity and is referred to again by Martianus Capella ${ }^{24}$ as well as by Servius in a comment on Vergil's Aeneid, 6.136:

latet arbore opacalaureus [ramus]: ... novimus Pythagoram Samium vitam humanam divisisse in modum y litterae, scilicet quod prima aetas incerta sit, quippe quae adhuc se nec vitiis nec virtutibus dedit: bivium autem y litterae a iuventute incipere, quo tempore homines aut vitia, id est partem sinistram, aut virtutes, id est dexteram partem sequuntur: unde ait Persius "traducit trepidas ramosa in compita mentes". ergo per ramum virtutes dicit esse sectandas, qui est y litterae imitatio.

("In the cover of a tree hides a golden bough: ... we know that Pythagoras of Samos divided the course of human life on the model of the letter $Y$, that is, the first stage of life is uncertain insofar as it has not yet given itself either to vice or to virtue. The divergence represented by the letter Y begins at the age of early adulthood when men follow either vice, i.e. what is wrong, or virtue, i.e. what is right. Just as Persius said '[life's witless

23 Combeaud, Opuscula, p. 691.

24 Mart. Cap. 2.102: litteram quoque, quam bivium mortalitatis asserere prudens Samius aestimavit, in locum proximum sumit ("in the next position she took a letter [Greek $\boldsymbol{Y}$ ], which the Samian sage Pythagoras regarded as representing the dual ambiguity of mortal fate.") [trans. Stahl, Johnson, \& Burge 1977]. 
wandering] delivers fearful minds into the crossway-fork. ${ }^{25}$ He means that the path to virtue resembles that of a branch in the shape of the letter Y.")

It is possible that this passage in Servius stems from the mid- $4^{\text {th }}$ cent. grammarian Aelius Donatus, who had been the teacher of Eusebius Hieronymus, the future St. Jerome. Of course, Jerome mentions the Pythagorean upsilon in a famous letter on the education of girls, Epist. 107.6 (ad Laetam de institutione filiae, c. 403): Qui autem parvulus est et sapit ut parvulus, donec ad annos sapientiae veniat et Pythagorae litterae eum perducant ad bivium, tam mala eius quam bona parentibus inputantur. ("When the son is a child and also thinks like a child, until he should come to those years of discretion that lead him to the crossroads implied in the letter of Pythagoras, both good behavior and bad behavior redound to the parents.")

The final mention of Pythagoras we meet in Ausonius appears in the Eclogues, wherein the Pythagorean practice of forming a tight-knit, philosophical community helps to shed light on the poet's comments on friendship, Ecl. 19.10, 31-4:
omne aevum curae, cunctis sua displicet aetas.
...
vive et amicitias semper cole. -Crimen ob istud
Pythagoreorum periit schola docta sophorum.
hoc metuens igitur nullas cole. -Crimen ob istud
Timon Palladiis olim lapidatus Athenis.

("Every stage of life has its troubles: all despise their own age. ... live your life and always cultivate friendships -on this charge the school of the Pythagorean sages died out. Then fearing this, make no friends- on this charge Timon was once stoned in Pallas' Athens.")

As R.P.H. Green notes, "this poem is an expanded version of AP 9.359

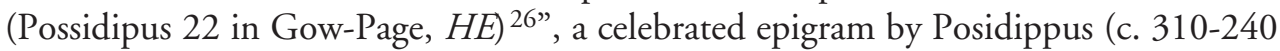
$\mathrm{BC}$ ) on the proper path to choose in life. It is no surprise that in perhaps the most important manuscript for Ausonius' works, the early ninth-century Leid. Voss. Lat. F 111 (V), we encounter the inscription: ex graeco pythagoricon ${ }^{27}$ de ambiguitate eligendae

25 Persius, Satires 5.35, on which see J.R. Jenkinson, Persius, The Satires, Warminster, Wiltshire, UK, 1980, ad loc., and cf. Pers. 3.56-57: et tibi quae Samios diduxit littera ramos/surgentem dextro monstravit limite callem. ("You too have been shown the Upward Path by the Samian's branching symbol and its right fork" trans. J.R. Jenkinson.)

26 Green, The Works of Ausonius, Oxford, 1991, p. 432.

27 Green, Works, p. 433, acknowledges that the word Pythagoricon in the V's title "could be authentic". 
vitae. (From the Greek, a Pythagorean poem on the double-edged nature of making life choices.") In the same manuscript, the name of Pythagoras is attached to the titles of the following two Eclogues (20-21), the first on the importance of self-examination in becoming (truly) good, and the second, again, on the need for a clarity of thinking in giving responses, i.e. "yes" or "no". ${ }^{28}$ There is no room in Ausonius for Pythagoras the political exile; he is merely a touchstone that suggests a kind of guide for ethical behavior. This is quite far from the moral reformer we meet in Ovid.

\section{Pythagoras in Martianus Capella}

In turning to Martianus Capella's bizarre didactic allegory on the seven liberal arts, De Nuptiis Philologiae et Mercurii ("The Marriage of Philology and Mercury"), we find the divine or rather divinized status of Pythagoras (and of Plato) of particular interest ${ }^{29}$. As noted above and as the Latin of my epigraph - mente deos adiit- is meant to indicate, Pythagoras' near divinity was also important for Ovid (Met. 15.60-65), precisely for the otherwise unobservable truth he revealed about the nature of the universe. In Martianus, Pythagoras' intellect is intimately connected with divinity, again because his great knowledge of the liberal arts made him like a $\operatorname{god}^{30}$. For example, in the following passage we read in Euterpe's praise of Philologia that, as the personification of pure knowledge, Philologia is responsible for the presence of the stars in the minds of both Pythagoras and Plato, that is, for bequeathing to both philosophers divine knowledge, Mart. Cap. 2.125:

virgo peritel praevia sortis, / quae potuistil scandere caelum/ sacraque castis/ dogmata ferre,/ noscere semet/ quis valuere, / quisque videntes/ lumine claro/ numina fati/ et geniorum/ cernere vultus, / quaeque Platonis/ Pythagoraequel esse dedistil sidera mentes.

28 The titles from the 9th cent. ms. V (= Leidensis Vossianus lat. 111) appear as follows [éd. GreEn 1999]: Ecl. 20: De viro bono. Pytagorice atioasis (On a good man: Pythagorean

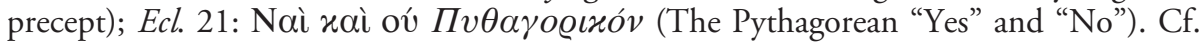
GreEN, Works, p. 432-33, on the similarities of these two eclogues with Ecl. 19 and the themes of Anth. Pal. 9.359.

29 The scholarship on the neo-platonic and neo-pythagorean elements of the De Nuptiis is vast, and the relevant work for the present study has been cited above in n. 22, including Наdot, Arts libéraux, p. 137-155, especially p. 145-148: "Ces deux noms de philosophes [sc. Platon et Pythagore] annoncent d'ailleurs la couleur du courant philosophique dans lequel se situe Martianus Capella"; Grebe, Martianus Capella, 1999; BoveY, Disciplinae Cyclicae; TurCan, "Martianus Capella et Jamblique"; Lenaz, Martiani Capellae... liber secundus.

30 Cf. Bover, Disciplinae Cyclicae, p. 346-347. 
("O maiden, our guide to skillful prophecy, who could ascend to heaven and bring down to pure souls the sacred teachings by which they were able to know themselves and by which they discerned and saw with clear light the decrees of fate and the countenances of the spirits, and you who allotted stars to be the minds of Plato and Pythagoras.") [trans. Harris, Stahl, \& Burge, 1977].

Later on in Book 8, both Pythagoras and Plato are found in a tight nexus among those poets and philosophers - e.g. Homer, Vergil, Aristotle, and Democritus, for example- who though once mortal had been added to the assembly of heaven because of what they had achieved in the arts, Mart. Cap. 8.803:

Quae dum geruntur et deorum sacer senatus illos numerorum concinentium repugnantiumque admiratur anfractus, ipsamque feminam quadam venerabilis excellentiae celsitudine reverendam non cassum parentem superum creditam recognoscit, multitudo etiam, quae iussa constiterat, sapientum - praesertimque Pythagoras cum sectatoribus cunctis Platoque Timaei sui caligosa discriminans-arcanis eam laudibus venerantur.

("Meanwhile the august company of the gods were amazed at the intricacies of the harmonious and discordant numbers [i.e. odd \& even], and acknowledged the lady herself, a majestic, exalted, and awe-inspiring figure, to be in very truth the procreator of the gods. And the host of philosophers, too, who stood nearby -in particular Pythagoras with all his disciples and Plato expounding the cryptic doctrines of his Timaeus- worship the lady with words of mystic praise.”) [trans. Harris, Stahl, \& Burge, 1977]

Although not explicit, there is clearly also a moral dimension at work here, an achievement of an ethical kind, in particular with regard to the instruction of the young.

What that instruction consisted in was, after all, Martianus' main concern in the Marriage of Philology and Mercury ${ }^{31}$, originally dedicated to his son. Here, however, Pythagoras is most often not a moral reformer or even suggestive of moral behavior as he was in Ausonius; he is rather the quintessential mathematician, who discovered the perfection of four and the so-called decad (in the form of the tetrachys), Mart. Cap. 2.106-07:

nam quaternarius suis partibus complet decadis ipsius poetestaem, ideoque perfectus est et habetur quadratus, ut ipse Cyllenius, cui anni tempora, caeli climata mundique elementa

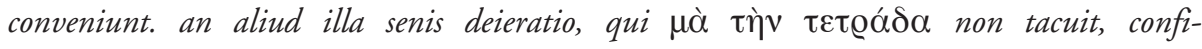
tetur nisi perfectae rationis numerum? quippe intra se unum, secundum triademque ipsum 
bis binum tenet, quis collationibus symphoniae peraguntur... hanc igitur discutiens numeri congruentiam perita virgo gratulatur.

("For the number four with its parts makes up the whole power of the decad itself [i.e. $1+2+3+4=10]$ and is therefore perfect and is called quadrate, as is the Cyllenian himself, with whom are associated the four seasons of the year, the regions of heaven, the elements of earth. That celebrated oath of old Pythagoras, who did not refrain from swearing 'by the tetrad' -what does that signify except the number of perfect ratio? Within itself it contains the one, the dual, the triad, and is itself the square of two, within which proportions the musical harmonies are produced... Thus in the examination of the agreement among numbers, the clever maiden [sc. Philologia] was delighted" ${ }^{32}$ ) [trans. Harris, Stahl, \& Burge 1977].

Later, in Book 3, he appears in Grammar's lesson on morphology ${ }^{33}$; similarly in Book 7, he appears in Arithmetic's lesson on numbers ${ }^{34}$. In Book 8, his work on astronomy is noted, Mart. Cap. 8.882: At Venus, quae ab aliis Phosphoros nominatur, a Pythagora cum suis ostensa est terris rationibus pervestigata ("But the planet Venus, which others call 'Phosphorus', was revealed to earth after it had been thoroughly investigated by Pythagoras and his followers.") Finally, in Book 9 -his last appearance in the workhis ability to work wonders with music is mentioned, Mart. Cap. 9.923:

32 To this is related the following representation in the same book, Mart. Cap. 2.213: Samius Pythagoras caelestes quosdam numeros replicabat ("The Samian Pythagoras was going over some heavenly numbers".)

33 Mart. Cap. 3.300: Graeca nomina, quae apud nos in as exeunt, tres species habent. prima est ut Olympias, Pythias, nam Olympiadis et Pythiadis facit; secunda ut Pallas, Thoas, Atlas, nam Pallantis... facit; tertia ut Aeneas, Pythagoras... nam Aeneae, Pythagorae... quomodo nostra ratione nomina quae genetivo in ae exeunt, nominativo in a, Catilinae Catilina. sed haec Graeca sunt; ideo in nominativo s litteram retinent. ("There are three kinds of Greek nouns which, when used in Latin, end in as: the first, like Olympias, Pythias, for their genitive Olympiadis, Pythiadis; the second, like Pallas, Thoas, Atlas, form it Pallantis, Thoantis, Atlantis; the third, like Aeneas, Pythagoras, Lichas, form it Aeneae, Pythagorae, Lichae, following the declension of those Latin nouns which have their genitive in ae and their nominative in $a$, like Catilinae from Catilina. These nouns, being Greek, keep the $s$ in the nominative") [trans. Harris, Stahl, \& Burge 1977].

34 Mart. Cap. 7.729: verum feminam Pythagoras, ut inter sapientes astabat, usque abacum consecutus, idemque iam artem, promere cupienti quandam lactei luminis facem officioso consistens munere praeferebat. tum illa antequam iuberetur, quid apportet, expromere, sic exorsa [sc. Arithmetica]. ("But Pythagoras, who was standing among the philosophers, followed after the lady as far as the abacus, and when she was ready to expound her discipline, he stood by her side and graciously held a bright torch before her. Then Arithmetic, before she was ordered to reveal what she brought, began to speak...") [trans. Harris, Stahl, \& Burge 1977]. 
Pythagorei etiam docuerunt ferociam animi tibiis aut fidibus mollientes cum corporibus adhaerere nexum foedus animarum. membris quoque latentes interserere numeros non contempsi; hoc etiam Aristoxenus Pythagorasque testantur.

("The Pythagoreans too assuaged the ferocity of men's spirits with pipes and strings and taught that there is a firmly binding relationship between souls and bodies. I did not disdain having numbers underlie the limbs of human bodies, a fact to which Aristoxenus and Pythagoras attest.”) [trans. Harris, Stahl, \& Burge 1977].

In short, he is the perfect philosopher for Martianus' teaching of the liberal arts, a polymath and ethical sage, a precursor to Plato and a son of Apollo. Indeed, he is like the gods, whom he approached not only in intellect (mens) but also in habit (mores).

\section{Conclusion}

I might sum up my findings here by saying that certain commonalities exist in the representation of the figure of Pythagoras in the three authors under investigation: Ovid, Ausonius, and Martianus Capella ${ }^{35}$. For obvious reasons, however, only Ovid is interested in Pythagoras' status as a political exile and how this relates to his ethical teaching and godlike intelligence. The political aspect of Pythagoras' life-story is of no consequence in Ausonius and Martianus Capella or, for that matter, anywhere else in the post-Ovidian tradition. Instead, these late-antique writers use the figure of Pythagoras as we might expect: for Ausonius he is an ethical sage, whose teaching -especially on the bivium and the letter $\mathrm{Y}$ - offers a conventional paradigm for moral instruction; for Martianus Capella he is even more, at once ethical sage, mathematician, and divine (or divinely-inspired) polymath who belongs in the company of Homer, Plato, Aristotle, and the greatest thinkers in the Greek philosophical tradition.

Matthew M. McGowAN

Associate Professor of Classics
Fordham University
Bronx, NY 10458 (USA)
mamcgowan@fordham.edu

35 Cf. Joost-Gaugier, Measuring Heaven, p. 76. 